\title{
Comparison of the quality of night paediatric urgent care in rural and urban areas of Lublin Province, eastern Poland - Appraisals by parents of children requiring medical attention
}

\author{
Barbara Kołłątaj', Witold Kołłątaj², Katarzyna Wrzołek², Irena Dorota Karwat ${ }^{1}$, Maria Klatka² \\ ${ }^{1}$ Chair and Department of Epidemiology and Clinical Research Methodology, Medical University of Lublin, Poland \\ ${ }^{2}$ Department of Paediatric Endocrinology and Diabetology, Medical University of Lublin, Poland
}

Kołłątaj B, Kołłątaj W, Wrzołek K, Karwat ID, Klatka M. Comparison of the quality of night paediatric urgent care in rural and urban areas of Lublin Province, eastern Poland - Appraisals by parents of children requiring medical attention. Ann Agric Environ Med. 2017; 24(1): 75-81. doi: $10.5604 / 12321966.1227645$

\begin{abstract}
I Abstract
Introduction. The quality of primary medical care for children in Poland is unsatisfactory. In the ranking known as 'the European Health Consumer Index', Poland (taking the patient point of view on healthcare quality) is classified on the 27th position out of the 33 possible. The unsolved problems concern inter alia the quality and availability of night paediatric urgent care.

Objective. The aim was assessing the quality as well as the level of satisfaction with the night paediatric urgent care in the Lublin Province of eastern Poland.

Materials and method. The materials for this study consisted of 540 parents of children aged 6-16 years benefiting from night paediatric urgent medical assistance in Lublin Province. The survey was conducted using the Original Survey Questionnaire.

Results. Inhabitants of the Lublin Province (regardless of place of residence) generally assessed the quality and accessibility of night paediatric urgent care facilities as only satisfactory. Inhabitants living in rural areas have worse access to night paediatric urgent care facilities because of having to travel greater distances, and receive less comprehensive medical assistance than inhabitants living in more urbanized areas, and they are more often referred to hospital emergency departments. During the past five years, both the availability and quality of night paediatric urgent care did not change significantly.

Conclusions. Inhabitants of the Lublin Province (regardless of place of residence) generally assessed the quality as well as accessibility of night paediatric urgent care facilities as only satisfactory. Rural residents have more reasons for dissatisfaction than urban dwellers. Both the quality and availability of such medical care needs to be improved.
\end{abstract}

\section{Key words:}

rural areas, urban areas, night, urgent care, children, comparison

\section{INTRODUCTION}

The quality of primary medical care for children in Poland is unsatisfactory. During the last two decades, paediatric primary care was entrusted to family doctors. Unfortunately, assigning responsibilities for prevention and treatment of children to physicians has been associated with deterioration in both prevention of diseases as well as diagnosing abnormal development in children [1]. Parents complain that they face many difficulties and see many irregularities concerning screenings and vaccinations - among them, inconvenient for parents, working hours of local clinics, waiting lists, long waits for doctors' appointments and periodic shortages of vaccines. They also have reservations about physical examination of children. The data published in 2014 by the Fund 'My Pacjenci' ('We Patients') suggest that the average waiting time for an appointment associated with the developmental screenings or vaccination of healthy children in Poland can be up to eight days [1].

Address for correspondence: Witold Kołłątaj, Department of Paediatric Endocrinology and Diabetology, Medical University of Lublin, Poland

E-mail:wk@data.pl

Received: 02 February 2016; accepted: 22 March 2016; first published on December, 2016
Incomplete implementation of screening procedures can be illustrated by the data provided by the Polish Central Statistical Office (Główny Urząd Statystyczny - GUS) in 2013 and 2014 [2]. The data being summed up results of information being sent to GUS (Reports ZD-3) [3] revealed that Polish family practitioners have performed screening tests and physically examined only $86 \%$ of the population of neonates/babies aged $0-6$ weeks and only $71 \%$ of babies aged 2-12 months of life [2]. Previously, in 2011 in Poland, only $76.3 \%$ of all 2 year-olds and $67 \%, 78.6 \%, 79.6 \%$ and $75.9 \%$ of all (subsequently) 4,6 , 10 and 13 years-old children/adolescents were provided with recommended screenings [4]. GUS also published information suggesting that only $66 \%$ of all children and youths aged 2-19 had been examined by doctors in accordance with the preventive screening schedule in 2013 [2].

The consequences of both the reform initiated in 1999 and the low expenditure on health service system in Poland manifest themselves as problems not only with providing appropriate preventive screening and health education, but also with medical assistance provided to children in emergency situations (sudden illness, sudden worsening of health status of chronically ill children) [5-9]. Such problems include: too few paediatricians, too few doctors, and inconvenient opening hours of local outpatients clinics. 
Nowadays, the average age of this type of specialists is equal to 58 years [10]. In 2010, there were 2,749 paediatricians working in all outpatient clinics in Poland (among them only 1,648 consultant paediatricians), which means one paediatrician per 22,000 members of the Polish population [4]. Poland is therefore a country where the lack of paediatricians is all too obvious. Such a status quo leads to many much inconvenience for both the children and their parents. General practitioners and family doctors, more frequently than paediatricians, refer patients to specialists, emergency departments and paediatric wards instead of diagnosing patients themselves. Being aware of such conditions in medical care, parents prefer paediatricians, although in practice not everyone has an equal amount of choice.

In the case of child's illness, many patients must wait up to several days: only $55 \%$ of them attain the medical advice of a paediatrician on the same day, and only $37 \%$ of parents have an opportunity to make an appointment with the doctor specializing in family medicine within dozen or so hours [1]. Parents, due to lack of satisfactory medical care in the place of residence, take their children to hospital emergency wards, make use of nocturnal urgent care facilities, or request fully-paid paediatrician home visits ( $15 \%$ of parents pay for the medical advice [1]).

In recent years, the number of young patients being hospitalized because of mild diseases, eligible for outpatient treatment, has increased. As many as one in four children (27\%) have received assistance from a hospital because the impossibility of obtaining medical aid in family medicine offices, or in specialist clinics [1].

In 2013, the number of people convinced about the steady decline in the quality of Polish health care system was almost six times higher than the number of Poles satisfied with changes in quality and accessibility of medical care [2]. It is therefore advisable to constantly monitor the facts and draw conclusions designed to improve the quality of medical care. In particular, it is advisable to carry out research on inequalities in access to health care in areas differing in the degree of urbanization, infrastructure and economic situation of regions.

\section{MATERIAL AND METHODS}

The materials for this study consisted of 540 parents of children and adolescents aged 6-16 years benefiting from night paediatric urgent care (abbreviation: NPUC) in the Lublin Province of eastern Poland, including the counties of Chełm, Lublin, Opole Lubelskie, Poniatowa, Puławy, and Radzyń Podlaski. Three subgroups of respondents were distinguished according to place of residence: 185 inhabitants of rural areas, 215 urban dwellers and 140 inhabitants of the city of Lublin, the capital of the Province (Tab. 1). The terminology concerning places of residence refer to the current territorial division of Poland [11].

While considering gender as well as education level, the data shown in the Table 1 suggest that groups living both in rural areas and in urbanized areas were very similar, although the differences were not statistically significant.

The study was conducted using a survey method. A special original standardized survey with 33 close-ended questions concerning details of the availability and quality of medical care/ NPUC services and satisfaction with medical help was
Table 1. Characteristics of groups of survey respondents

\begin{tabular}{llccc}
\hline & \multicolumn{3}{c}{ Place of residence } \\
\cline { 2 - 5 } & & Rural areas & Urban areas & Lublin \\
\hline No. of surveyed parents & 185 & 215 & 140 \\
\hline \multirow{2}{*}{ Gender } & Males [n (\%)] & $13(7)$ & $18(8.3)$ & $8(5.7)$ \\
\cline { 2 - 5 } & Females [n (\%)] & $172(93)$ & $197(91.7)$ & $132(94.2)$ \\
\hline \multirow{2}{*}{$\begin{array}{l}\text { Education } \\
\text { level }\end{array}$} & Higher education [n (\%)] & $90(48.6)$ & $118(54.9)$ & $103(73.6)$ \\
\cline { 2 - 5 } & Secondary education [n (\%)] & $94(50.8)$ & $91(42.3)$ & $36(25.7)$ \\
\cline { 2 - 5 } & Primary education [n (\%)] & $1(0.5)$ & $6(3)$ & $1(0.7)$ \\
\hline
\end{tabular}

used. The survey was carried in October 2014 in randomly selected primary and secondary schools. The questionnaires were distributed and with the consent of headmasters, by teachers - class tutor having custody of children of the surveyed parents - questionnaires were filled out by parents individually in their homes and then returned to class tutors in the schools. Almost $82 \%$ of the survey questionnaires were returned.

Statistical methods. Most of the obtained data were answers to questions based on a rating scale with balanced keying - a 5 -point Likert opinion scale (answers expressed as integers in the range of $1-5$ or -2 to 2 ), or on interval scale (grouped data).

To analyse data based on the Likert scale, basic statistic methods were applied (number of answers, median and modal values calculations). While analysing data presented in Figures 3 and 4, grouped data statistics were used to estimate: - mode values (observation with the maximum frequency) defined in the algebraic expression below:

$$
\text { mode }=L+\frac{(F-F 1)}{(F-F 1)+(F-F 2)} \times h
$$

where:

$\mathrm{L}=$ lower limit of the modal class; $\mathrm{F}=$ frequency of the modal class; F1 = frequency of the class immediately previous to modal class; F2 = frequency of the class immediately next to modal class; $\mathrm{h}=$ range of the modal class (higher limit - lower limit);

- median values (preceded by identifying median classes); medians calculated by the following formula:

$$
\text { median }=L+\left(\frac{\frac{n}{2}-c f}{F}\right) \times h
$$

where:

$\mathrm{n}=$ number of observations;

$\mathrm{L}=$ lower limit of median class;

$\mathrm{cf}=$ cumulative frequency of class prior to median class;

$\mathrm{F}=$ frequency of median class;

$\mathrm{h}=$ class size (higher limit - lower limit).

Other statistics were performed with the use of Statistica 10 software [12].

Data concerning answers given by respondents and expressed in a 5-point scale were analysed by use of the Mann-Whitney test (to compare two independent groups) or Kruskal- Wallis ANOVA test by Ranks, Median test (abbreviation: K-W test) to compare attitudes and opinions expressed by both villagers, residents of small towns and residents of the city of Lublin. All tests were run with an alpha level of .05 (5\%). 


\section{RESULTS}

Evaluation of the quality of the NPUC should be discussed in the context of local needs in a given area (including the availability of paediatric care), waiting time for advice, qualifications of the staff providing medical services, quality of medical assistance and patient satisfaction. Therefore, the results of the study are presented in the form of thematic sub-blocks including specifying the above-mentioned issues.

The numbers in Tables and Figures may not add up to exactly $100 \%$ due to rounding errors.

Assessment of the availability of paediatric care in respondents' place of residence. The majority of polled parents assessed the availability of paediatric care in their place of residence as 'average' and 'good' ('3' and '4') (Fig. 1).

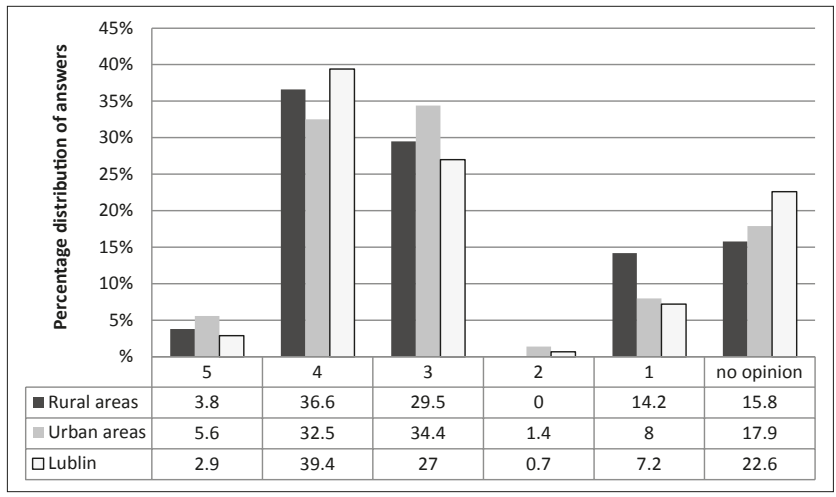

Figure 1. Percentage distribution of answers to the question: 'How would you rate the availability of paediatric care?' (Likert scale: 1-very bad, 5-very good)

After excluding the option 'no opinion' - modal values were as follows: inhabitants of Lublin - ' 3 ', inhabitants of urban areas - '4', inhabitants of rural areas - '4' (Tab. 2). Median values were equal to ' 3 ' $(\mathrm{K}-\mathrm{W}$ test; $\mathrm{p}$-value $=.960)$.

Table 2. Availability of paediatric care in place of residence (valid answers).

\begin{tabular}{lcccc}
\hline \multirow{2}{*}{$\begin{array}{l}\text { Place of } \\
\text { residence }\end{array}$} & Availability of paediatric care in of respondents' place of residence \\
\cline { 2 - 5 } & N valid & $\begin{array}{c}\text { Median value } \\
\text { (Rank) }\end{array}$ & $\begin{array}{c}\text { Modal value } \\
\text { (Rank) }\end{array}$ & $\begin{array}{c}\text { Frequency of } \\
\text { Mode }\end{array}$ \\
\hline Lublin & 105 & 3 & 3 & 45 \\
\hline Urban areas & 171 & 3 & 4 & 69 \\
\hline Rural areas & 149 & 3 & 4 & 64 \\
\hline
\end{tabular}

Demand for NPUC in selected areas of Lublin Province. The starting point for discussion about the quality of NPUC in areas differing in terms of urbanization and infrastructure is to determine the differences in demands for such care depending on place of residence (Fig. 2).

The majority of children of surveyed parents (regardless of place of residence) have needed NPUC help at least once in their lives. The differences between percentages were not statistically significant (K-W test; Ranks: Never - 0; Yes, Once -1 ; Several times -2 ; p-value $=1.000$ ).

Distance from place of residence of the child to NPUC facility. Distance determined by usage of the interval scale. Summarized answers to the question: 'How far is it from your place of residence to the nearest NPUC facility?' are shown in (Fig. 3).

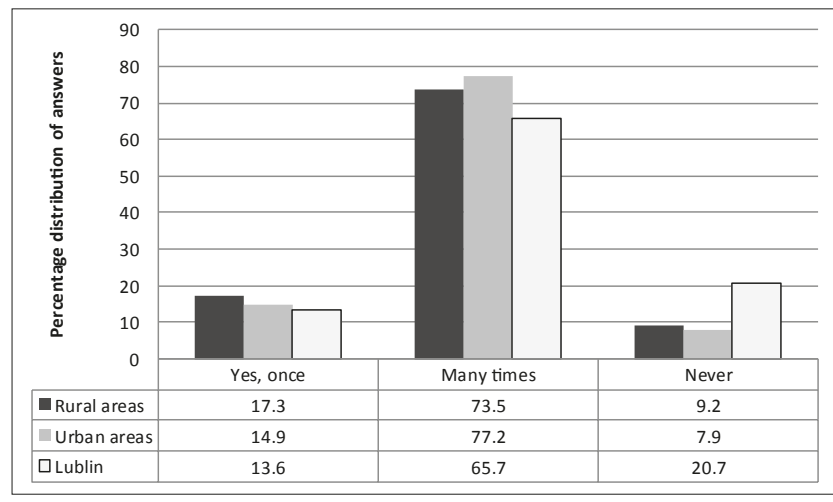

Figure 2. Percentage distribution of answers to the question: 'Has your child ever benefited from night paediatric urgent care?'

Table 3. Distances from child's place of residence to the nearest night paediatric urgent care facility - interval scale and assigned ranks

\begin{tabular}{lccccccc}
\hline & \multicolumn{7}{c}{$\begin{array}{c}\text { Distance from child's place of residence to the nearest night } \\
\text { paediatric urgent care facility }\end{array}$} \\
\hline Distance $(\mathrm{km})$ & Up to 2 & $2-3$ & $4-5$ & $6-10$ & $11-15$ & $16-20$ & More than 20 \\
\hline Rank & 1 & 2 & 3 & 4 & 5 & 6 & 7 \\
\hline
\end{tabular}

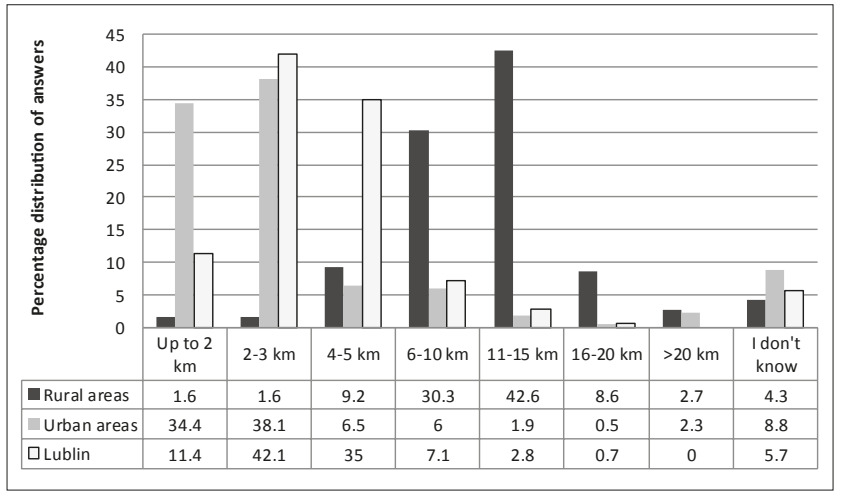

Figure 3. Percentage distribution of answers to the question: 'How far is it from your place of residence to the nearest night paediatric urgent care facility?'

The obtained data suggest that in situations requiring medical intervention, inhabitants of rural areas have to travel far greater distances than Lublin citizens or inhabitants of other urban areas. The differences were statistically significant $(\mathrm{K}-\mathrm{W}$ test; $\mathrm{p}$-value $=.000)$. Median and modal values are listed in Table 4.

Table 4. Distances from child's place of child residence to the nearest night paediatric urgent care facility - median and modal values (valid answers)

\begin{tabular}{lccccccc}
\hline & \multicolumn{6}{c}{$\begin{array}{c}\text { Distance from the place of child residence to nearest night } \\
\text { paediatric urgent care facility }(\mathrm{km})\end{array}$} \\
\cline { 2 - 8 } $\begin{array}{l}\text { Place of } \\
\text { residence }\end{array}$ & $\mathrm{N}$ valid & $\begin{array}{c}\text { Median } \\
\text { value } \\
(\text { Rank })\end{array}$ & $\begin{array}{c}\text { Median value } \\
(\mathrm{km})\end{array}$ & $\begin{array}{c}\text { Modal } \\
\text { value } \\
(\text { Rank })\end{array}$ & Modal value $(\mathrm{km})$ \\
\cline { 2 - 8 } & 130 & 2 & $2-3$ & 3.66 & 2 & $2-3$ & 3.39 \\
\hline Lublin & 193 & 2 & $2-3$ & 2.54 & 2 & $2-3$ & 2.23 \\
\hline Urban areas & 177 & 5 & $11-15$ & 11.62 & 5 & $11-15$ & 12.28 \\
\hline Rural areas & & & $\mathrm{a}$ & $\mathrm{B}$ & $\mathrm{a}$ & $\mathrm{a}$ & $\mathrm{b}$ \\
\hline
\end{tabular}

a) Interval scale statistics (nonparametric rank statistics)

b) Grouped data statistics 
Average waiting time for medical advice in the nearest NPUC facility. The waiting time for medical advice in NPUC facilities is shown in Figure 4. The intervals and assigned ranks are described in Table 5; median and modal values are listed in Table 6.

Table 5. Average waiting time for medical advice in the nearest night paediatric urgent care facility - interval scale and assigned

\begin{tabular}{lccccc}
\hline \multicolumn{5}{c}{ Average waiting time for medical advice } \\
\hline $\begin{array}{l}\text { waiting time } \\
\text { - intervals }\end{array}$ & At once & $\begin{array}{c}\text { Up to } 30 \\
\text { minutes }\end{array}$ & $\begin{array}{c}30-59 \\
\text { minutes }\end{array}$ & $1-2$ hours & $\begin{array}{c}\text { More than } \\
\text { 2 hours }\end{array}$ \\
\hline Rank & 0 & 1 & 2 & 3 & 4 \\
\hline
\end{tabular}

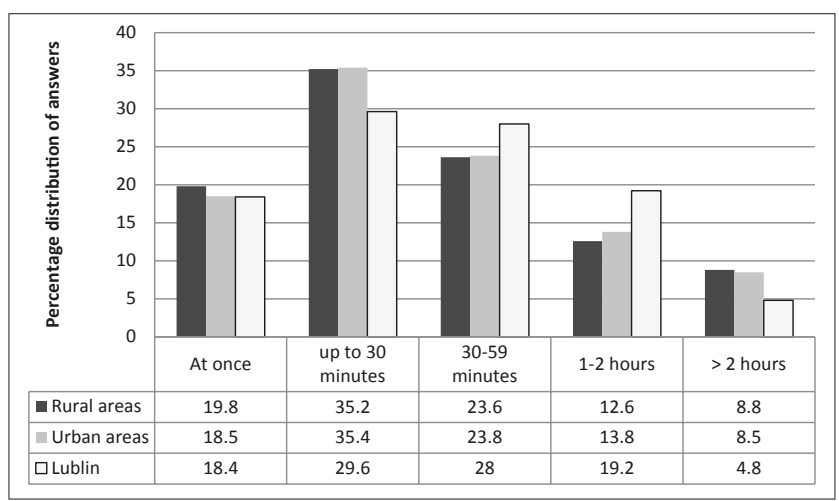

Figure 4. Average waiting time for medical advice in the nearest night paediatric urgent care facility

Table 6. Average waiting time for medical advice in the nearest night paediatric urgent care facility - median and modal values

\begin{tabular}{lccccccc}
\hline & \multicolumn{6}{c}{ Average waiting time for medical advice in the nearest night } \\
paediatric urgent care facility
\end{tabular}

a) Interval scale statistics (non-parametric rank statistics);

b) Grouped data statistics.

Among the answers specifying the waiting time for medical advice in NPUC the most frequent was 'up to 30 minutes '(regardless of place of residence). The differences between the answers (analysed median values) given by Lublin dwellers as well rural an urban inhabitants were not statistically significant $(\mathrm{K}-\mathrm{W}$ test; $\mathrm{p}$-value $=.207)$.

Professional qualifications of doctors employed in NPUC facilities. Analysis of the professional qualifications of doctors employed in NPUC facilities reveals that the managers of NPUC facilities located in all analysed areas prefer paediatricians and family medicine doctors to unqualified doctors (Fig. 5). The differences between qualifications of the doctors employed in such facilities in all analysed areas were not statistically significant (K-W test; Ranks: Family medicine doctors - 1; Paediatricians - 2; General practitioners $-0 ; \mathrm{p}$-value $=.499)$

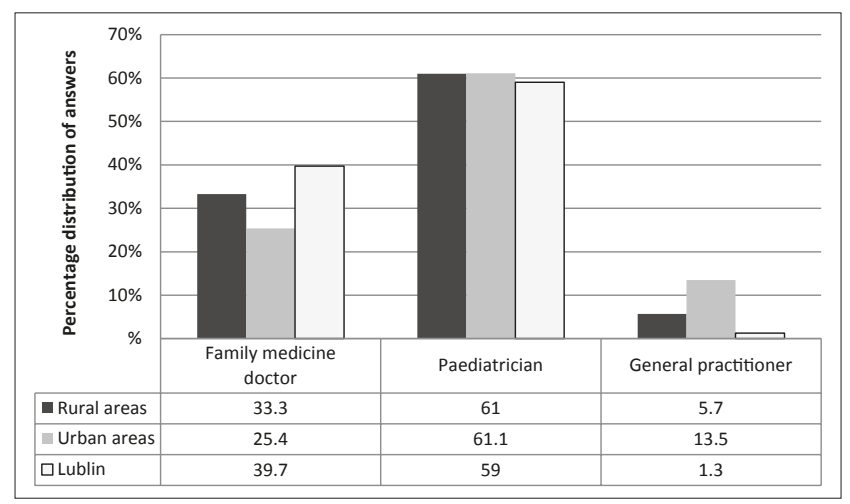

Figure 5. Professional qualifications of the doctor employed in the nearest night paediatric urgent care facility

Assessment of competence of medical stuff employed in NPUC facilities according to analysis of data concerning the number of children referred to emergency departments/ hospitals. Assessment of the competence of doctors and the quality of medical services can be carried out by analysis of the statistical data on the medical advice given by the issuing of a prescription, and making medical recommendations and advice given by referring patients to another doctor, especially to the nearest hospital emergency department (Fig. 6).

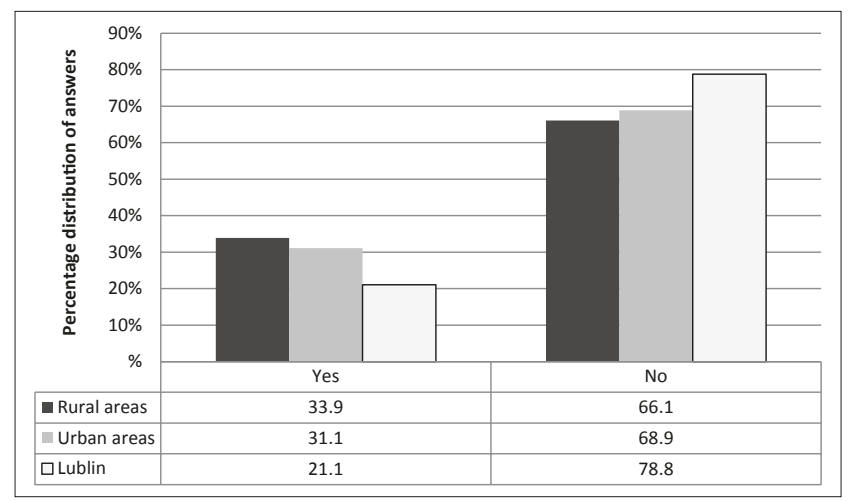

Figure 6. Answers to the question: 'Has the doctor who was employed in night paediatric urgent care facility referred your child to a hospital emergency department?'

The differences between answers given by inhabitants living in rural and urban areas, as well as in Lublin city, were statistically significant (K-W test; Ranks: Yes - 1; No - 0; $\mathrm{p}-$ value $=.034)$.

Children living in rural areas who have required NPUC were significantly more likely to have been referred to hospitals than children from urban areas, including Lublin city (Lublin area versus rural areas - differences statistically significant - Mann-Whitney U test; p-value .007; Lublin area versus urban areas - differences not statistically significant (Mann-Whitney U test; p-value .078)).

Assessment of quality of NPUC. Among answers to the question: 'How would you rate the quality of NPUC?', the most common were: 'average' or 'good' ('3' or '4') (Fig. 7).

While excluding the option 'no opinion', median values were as follows: inhabitants of Lublin - ' 3 ', inhabitants of urban areas - '4', inhabitants of rural areas - '4' (Tab. 7). The differences between the assessments carried out by urban and 


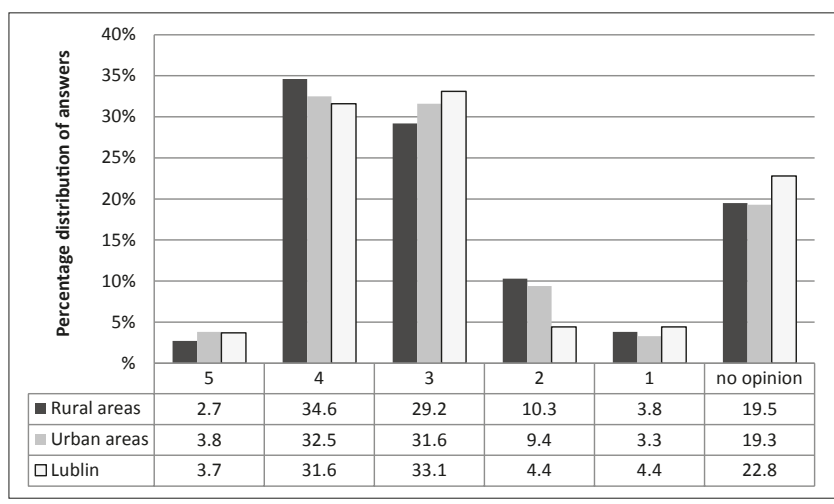

Figure 7. Percentage distribution of answers to the question: 'How would you rate the quality of night paediatric urgent care?' (Likert scale: 1 - very bad; 5 - very good)

rural residents, as well as Lublin citizens, were not statistically significant $(\mathrm{K}-\mathrm{W}$ test; $\mathrm{p}$-value $=.974)$

Table 7. Answers to the question: 'How would you rate the quality of night paediatric urgent care?'

\begin{tabular}{lccc}
\hline \multirow{2}{*}{$\begin{array}{l}\text { Place of } \\
\text { residence }\end{array}$} & N valid & Median value (items) & Modal value (items) \\
\cline { 2 - 4 } & 105 & 3 & 3 \\
\hline Lublin & 171 & 3 & 4 \\
\hline Urban areas & 149 & 3 & 4 \\
\hline Rural areas & &
\end{tabular}

Assessment of changes in the quality NPUC that have taken place during the last 5 years. Assessment illustrated by data in Figure 8 and Table 8.

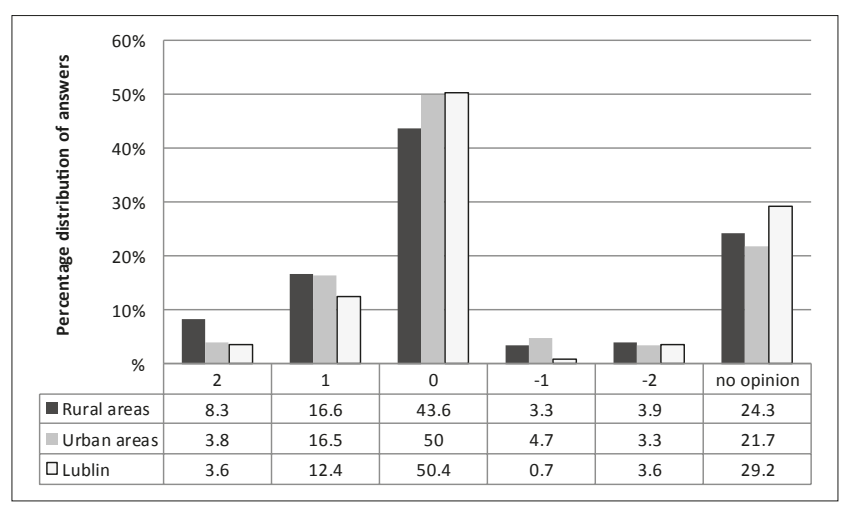

Figure 8. Percentage distribution of answers to the question: 'How would you rate the changes in quality of night paediatric urgent care that took place during the last 5 years?' (scale: +2 - a significant improvement; +1 - slight improvement; 0 - no changes; -1 - slight deterioration; -2 - significant deterioration)

Table 8. Answers to the question: 'How would you rate the changes in quality of night paediatric urgent care that took place during the last 5 years?'

\begin{tabular}{lccc}
\hline & $\begin{array}{c}\text { N (valid, i.e. -'no } \\
\text { option' excluded)) }\end{array}$ & Median value (Rank) & Modal value (Rank) \\
\hline Rural areas & 99 & 0 & 0 \\
\hline Urban areas & 169 & 0 & 0 \\
\hline Lublin & 140 & 0 & 0 \\
\hline
\end{tabular}

Most of the parents were of the opinion that in the last 5 years there have been no changes in quality of NPUC. The differences between assessments made by people living in the designated areas of Lublin Province were not statistically significant $(\mathrm{K}-\mathrm{W}$ test; $\mathrm{p}$-value $=.137)$.

Assessment of availability of NPUC in the place of residence of respondents that have taken place during the last 5 years.

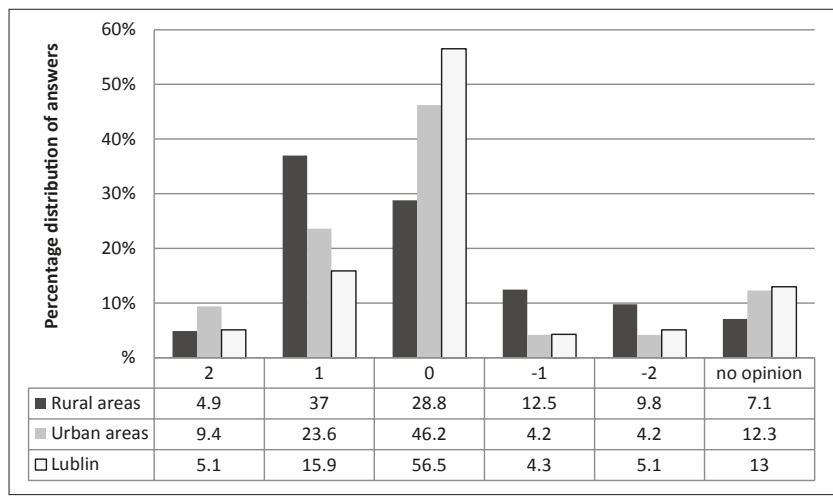

Figure 9. Percentage distribution of answers to the question: 'How would you rate the changes in the availability of the night paediatric urgent care in your place of residence that have taken place during the last 5 years?' (scale: $+2-$ significant improvement; +1 - slight improvement; 0 - no changes; -1 - slight deterioration; -2 - significant deterioration)

Table 9. Answers to the question: 'How would you rate the changes in the availability of night paediatric urgent care that have taken place during the last 5 years in your place of residence?' Assigned ranks

\begin{tabular}{lccccc}
\hline \multicolumn{5}{c}{ Changes in the availability of night paediatric urgent care } \\
\hline Opinion & $\begin{array}{c}\text { Significant } \\
\text { improve- } \\
\text { ment }\end{array}$ & $\begin{array}{c}\text { Slight } \\
\text { improve- } \\
\text { ment }\end{array}$ & $\begin{array}{c}\text { No } \\
\text { changes }\end{array}$ & $\begin{array}{c}\text { Slight } \\
\text { deterio- } \\
\text { ration }\end{array}$ & $\begin{array}{c}\text { Significant } \\
\text { deterio- } \\
\text { ration }\end{array}$ \\
\hline Rank & 2 & 1 & 0 & -1 & 2 \\
\hline
\end{tabular}

Table 10. Answers to the question: 'How would you rate the changes in the availability of night paediatric urgent care in that have taken place during the last 5 years in your place of residence?' Descriptive statistics, including only valid cases (excluded option: 'no opinion')

\begin{tabular}{lccc}
\hline & $\begin{array}{c}\text { N (valid, i.e.-'no } \\
\text { option' excluded)) }\end{array}$ & Median value (Rank) & Modal value (Rank) \\
\hline Rural areas & 161 & 0 & 0 \\
\hline Urban areas & 189 & 0 & 0 \\
\hline Lublin & 121 & 0 & 0
\end{tabular}

In general, parents living in the Lublin Province (regardless of place of residence) have not noticed any changes in the availability of NPUC in the last 5 years (K-W test; p-value $=.055)$.

\section{DISCUSSION}

Health is one of the most important domains of overall quality of life. It is as important with regard to, for instance, jobs, housing, schools, and the neighbourhood.

Article 12 of the International Covenant on Economic, Social and Cultural Rights (ICESCR) suggests putting into practice central international protection for everyone's right to enjoy the highest attainable standard of physical and mental health ('the right to health') [13]. Which is why, among the most important strategic objectives in many countries, health care seems to be one of the most important. 
The quality of health care can be evaluated relying on subjective indicators (self-evaluation of one's health, as well as patients' attitudes and perceptions towards healthcare services), and objective measures (waiting time, the number of doctors per 1 patient, working hours of clinics, costs, convenience and availability of urgent care services, geographic access to clinics, etc.). Subjective measures are used to assess health-related quality of life (HRQOL) [14-18] although it must be remembered that patient satisfaction does not mean the best medical care.

In many economically developed countries the overall mean (or median) satisfaction with primary health care centres services in recent years has usually been $3-4$ points out of 5 (rarely more): Kuwait mean: 3.1 points in 2001 [19]; Makkah region (Saudi Arabia) - mean: 61.5 points out of 75 - i.e. 4.1 points out of 5 in 2008 [20]; Finland - 3 points out of 5 in 2011 [21]; Latvia, Slovakia, Hungary, Greece, Estonia - median 3 points; France - median 4 points in 2003 [22]; Italy, Ireland, Sweden, Spain, UK - median values 4 points of 5 in 2009; Austria, Belgium and Denmark - median 5 points out of 5 in 2003 [22]).

The median values describing satisfaction of people living in the Lublin region (Fig. 1, Tab. 2, Fig. 7, Tab. 7) were equal to 3 points of 5 (regardless of places of residence of respondents). Such opinions concerned only selected aspects of the health care (NPUC), and the selected group of patients and did not reflect the complexity of primary health care. The presented observations suggest that the quality of medical care in Poland (expressed by the level of patient satisfaction) does not stand out against the satisfaction expressed by the inhabitants of Latvia, Slovakia, Hungary, Greece and Estonia in 2003, and is much worse than the quality of medical care reported in most European countries in 2003 (especially in Austria, Belgium and Denmark) [22]. The lack of reliable and widely available data on the quality of medical care in Europe in the last 10 years do not permit more valid comparisons.

No satisfaction with paediatric care should motivate the making of plans for organisational and management changes, and to put into effect increases in health care expenditure.

In some developed countries, more than $10-11 \%$ of the GDP (Gross Domestic Product) is allocated to health care (17.7\% in the USA in 2013 and $11.2 \%$ in Canada [23]). In the European OECD countries the highest expenditures on health care (calculated as a percentage of GDP) were allocated by Switzerland (11.1\%), Netherlands (11.1\%) and France (10.9\%), and the lowest - in Turkey (5.1\%), Estonia (6.0\%) and Poland (6.4\%) [23]. In Poland, the expenditure on health care, expressed as a share of the GDP, has been steadily declining for a number of years (7.21\% in 2009, $6.8 \%$ in 2011, $6.4 \%$ in 2012) $[2,23,24]$. The per capita annual expenditure on health care in European OECD countries in 2013, were in the range of USD 906 - 5,669 (the highest expenditures: Norway - 5,669, Switzerland - 5,643, Netherlands - 5,009, and the lowest: Hungary - 1,689, Poland - 1,452, Russian Federation - 1,303 and Turkey - 906) [25].

In 2013, Poland was the country with highest percentage (among all OECD countries) of reported unmet medical needs [25]) and one of the lowest expenditures on healthcare (per capita annual expenditure). This state of affairs results in the possibility of improving the quality of health care through increasing management efficiency and modifying existing procedures seem less and less realistic.
While analysing the data shown in Figure 3 and Table 4, the conclusion is evident, that inhabitants living in rural areas have worse access the NPUC facilities than other inhabitants of Lublin Province. Such inequalities in access to health care result from the non-equitable distribution of healthcare facilities, caused by economic reasons. It is rather unlikely that such a state of affairs can be changed without evident increase in expenditure on health care.

There is a question about the possible sources of money and the model for financing Polish health care. After World War II, the Polish health care system was modelled on the Soviet Siemaszko concept [26], the main assumptions of which were a strong centralization of budget funding. In 1999, the health system was transformed into a system resembling the Bismarck model $[26,27]$ which uses an insurance system and is based on financial resources originating from only one fund. The problem is that Poland is a country where there is a relatively high rate of unemployment, relatively low wages and high taxes. This means taking into consideration both sources of funding and financing of the model health care system (Bismarck model), and that expectations for a significant increase in spending on health care in the immediate future are irrational. There are suggestions that in Poland the best solution would be a National Health Insurance Model based on both the Beveridge (resembling the Siemaszko concept) and Bismarck models. Unfortunately, this proposal does not seem to be suitable because Poland is a country with high budget deficits, and it is expected that the largest ever budget deficit will be announced this year.

\section{CONCLUSIONS}

1. Inhabitants of the Lublin Province (regardless of place of residence) generally assess the quality as well as accessibility of night paediatric urgent care facilities as satisfactory.

2. Rural residents have more reasons for dissatisfaction than urban dwellers.

3. Both the quality as well as the availability of such medical care needs to be improved.

\section{REFERENCES}

1. Borek E, Libura M, Chwiałkowska A, Kołodziej M, Turkiewicz J. Profilaktyka pediatryczna w Polsce z perspektywy rodziców małych dzieci. Warszawa: Fundacja My Pacjenci, Fundacja NUTRICIA; 2014 (in Polish).

2. Żyra M [ed]. Central Statistical Office. Health and Health Care in 2013. Warsaw: Central Statistical Office; 2014. http://www.stat.gov. pl/_(access 25.11.2015).

3. GUS. ZD-3. Sprawozdanie z ambulatoryjnej opieki zdrowotnej. Portal sprawozdawczy GUS www.stat.gov.pl. Kraków 2013 (in Polish). http:// form.stat.gov.pl/formularze/2012/passive/ZD-3.pdf(access 25.11.2015).

4. Falkowska E, Telusiewicz-Pacak A [ed.]. Dzieci w Polsce. Dane, liczby, statystyki. Warszawa: Polski Komitet Narodowy UNICEF; 2013 (in Polish).

5. Huk-Wieliczuk W, Wdowiak L. State of health of adolescents in eastern regions of Poland. Podlasie regionchild. Ann Agric Environ Med. 2006; 13(1): 39-43.

6. Sagan A, Panteli D, Borkowski W, Dmowski M, Domański F, Czyżewski M, et al. Poland: Health system review. Health Systems in Transition, 2011; 13(8): 1-193.

7. CSIOZ. Dostępność świadczeń zdrowotnych w opinii Polaków - raport $z$ badań. [Access to health care in opinion of Poles - research report]. Warsaw: Centrum Systemów Informacyjnych Ochrony Zdrowia [Centre for Health Information Systems]; 2008 (in Polish). 
8. Rodakowska E, Wilczyńska-Borawska M, Bagińska J, Stokowska E. Epidemiological analysis of dental caries in 12-year-old children residing in urban and rural settings in the Podlaskie region of northeastern Poland. Ann Agric Environ Med. 2013; 20(2): 325-328.

9. Charzyńska-Gula M, Sygit K, Sygit M, Goździewska M, Dobrowolska B, Gałęziowska E. Problems of health education in rural areas in Poland. Ann Agric Environ Med. 2013; 20(3): 515-522.

10. Termedia. Średnia wieku polskich pediatrów to... 58 lat. Menadżer Zdrowia. Warszawa, 2011. http://www.termedia.pl/mz/Srednia-wiekupolskich-pediatrow-to-58-lat,4196.html (access 25.11.2015).

11. Markowski T, Marszał T. Metropolie, obszary metropolitalne, metropolizacja. Problemy i pojęcia podstawowe. Komitet Przestrzennego Zagospodarowania Kraju PAN. Warszawa, 2006 (in Polish).

12. StatSoft, Inc. (2012). STATISTICA (data analysis software system), version 10.0. www.statsoft.com. (Site_License/luB9721um.php).

13. Manderson L. Disability, global legislation and human rights. Development. 2004; 47(2): 29-35.

14. Carr-Hill RA. The measurement of patient satisfaction. J Public Health Med. 1992; 14: 236-249.

15. Crow R, Gage H, Hampson S, Hart J, Kimber A, Storey L, et al. The measurement of satisfaction with healthcare: implications for practice from a systematic review of the literature. Health Technol Assess. 2002; 6: 1-244.

16. Hudak PL, Wright JG. The characteristics of patient satisfaction measures. Spine. 2000; 25: 3167-3177.

17. Ross CK, Stewart CA, Sinacore JM. A comparative study of seven measures of patient satisfaction. Med Care. 1995; 33: 392-406.
18. Jackson JL, Chamberlin J, Kroenke K. Predictors of patient satisfaction Soc Sci Med. 2001; 52: 609-620.

19. Al-Doghaither AH, Abdelrhman BM, Saeed AAW, Al-Kami AAl, MCommH, Majzoub MM. Patients' Satisfaction With Primary Health Care Centers Services In Kuwait City, Kuwait Family Community Med. 2001; 8(3): 59-65.

20. Al-Hoqail IA, Abdalla AM, Saeed AA, Al-Hamdan NA, Bahnassy AA. Pilgrims satisfaction with ambulatory health services in Makkah, 2008. J Family Community Med. 2010; 17(3): 135-140.

21. Raivio R, Jääskeläinen J, Holmberg-Marttila D, Mattila KJ. Decreasing trends in patient satisfaction, accessibility and continuity of care in Finnish primary health care - a 14-year follow-up questionnaire study. BMC Family Practice. 2014; 15: 98.

22. Bleich SN, Özaltin E, Murrayc CJL. How does satisfaction with the health-care system relate to patient experience? Bull World Health Organ. 2009; 87(4): 271-278.

23. OECD.stat. Health expenditure and financing. http://stats.oecd.org/ index.aspx? DataSetCode=SHA (access 25.11.2015).

24. WHO. World health report 2010. Health Systems Financing. WHO, 2011. http://www.who.int/healthsystems (access: 2015.11.15).

25. OECD (2013), Health at a Glance 2013: OECD Indicators, OECD Publishing.http://dx.doi.org/10.1787/health_glance-2013-en (access: 2015.11.15).

26. Suchecka J (ed.). Finansowanie ochrony zdrowia. Wybrane zagadnienia. Warszawa: Wolters Kluwer; 2011: 23-64.

27. Suchecka J. Ekonomia zdrowia i opieki zdrowotnej. Warszawa: Wolters Kluwer; 2010: 13-69. 